\title{
ANALISIS BIAYA TRANSAKSI USAHATANI PADI DI KECAMATAN BANGKINANG KABUPATEN KAMPAR
}

\author{
Analysis of Transactions Cost of Rice Farming in Bangkinang District, \\ Kampar Regency
}

\author{
Ilma Satriana Dewi, Septina Elida, Dini Amalia Putri \\ Program Studi Agribisnis, Fakultas Pertanian, Universitas Islam Riau, Pekanbaru, Riau. \\ email: ilmasatrianadewi@agr.uir.ac.id \\ [Diterima: Juli 2019; Disetujui: Agustus 2019]
}

\begin{abstract}
The rice plant is one of the agricultural products and is a major food for almost all the people of Indonesia. Farming capital is the production cost that will be spent by farmers during the production process. However, in addition to production costs, there are other costs unwittingly incurred by farmers which are also related to their farming activities. These costs are known as transaction costs. The purpose of this study was to analyze components and total transaction costs and the effect of transaction costs on economic efficiency of rice farming. The data were analyzed using descriptive qualitative and quantitative descriptive approaches. Transaction cost was analyzed by using transaction cost analysis. The results showed that the components of rice farming transaction costs along with their ratio consisting of information costs $(0,05)$, negotiation costs $(0,02)$, coordination costs $(0,79)$, implementation costs $(0,03)$, risk costs $(0,08)$ and transportation costs $(0,03)$. The effect of transaction costs on revenue was seen from the ratio value which wais equal to 0,009 . Meanwhile, the factors that significantly affect transaction costs were farming experience and subscription.
\end{abstract}

Keywords : rice, transaction costs, revenue.

\begin{abstract}
ABSTRAK
Tanaman padi merupakan salah satu produk pertanian dan sebagai pangan utama bagi hampir seluruh masyarakat Indonesia. Modal usahatani padi merupakan biaya produksi yang akan dikeluarkan petani selama proses produksi. Namun, selain biaya produksi ada biaya lain yang dikeluarkan oleh petani tanpa disadari yang juga berkaitan dengan kegiatan usahataninya. Biaya tersebut dikenal dengan istilah biaya transaksi. Tujuan penelitian ini adalah untuk menganalisis komponen dan jumlah biaya transaksi, dan menganalisis pengaruh biaya transaksi terhadap efisiensi ekonomi. Metode analisis data yang digunakan adalah secara deskriptif kualitatif dan deskriptif kuantitatif. Analisis biaya transaksi digunakan dengan transaction cost analysis. Hasil penelitian menunjukkan bahwa komponen penyusun biaya transaksi usahatani padi beserta rasionya terdiri dari biaya informasi $(0,05)$, biaya negosiasi $(0,02)$, biaya koordinasi $(0,79)$, biaya pelaksanaan $(0,03)$, biaya risiko $(0,08)$ dan biaya transportasi $(0,03)$. Adapun pengaruh biaya transaksi terhadap penerimaan dilihat dari nilai nisbahnya yaitu sebesar 0,009 . Sementara itu, faktor-faktor yang berpengaruh nyata terhadap biaya transaksi adalah pengalaman berusaha dan iuran.
\end{abstract}

Kata kunci: padi, biaya transaksi, penerimaan usahatani.

\section{PENDAHULUAN}

Tanaman padi termasuk ke dalam salah satu jenis tanaman pangan yang dikonsumsi oleh hampir seluruh masyarakat di Indonesia. Banyaknya masyarakat yang memilih padi sebagai bahan pangan karena tanaman padi yang menghasilkan beras memiliki kandungan karhodirat yang cukup tinggi yaitu sekitar $80-85 \%$. Selain kandungan karhodirat yang tinggi, alasan lainnya karena padi atau beras mudah diperoleh, harganya yang terjangkau dan cita rasanya yang enak dan bisa diterima oleh semua masyarakat dibandingkan bahan pangan lainnya.

Provinsi Riau merupakan salah satu daerah yang juga menghasilkan tanaman padi. Sejalan dengan kondisi produksi padi di Indonesia, provinsi Riau juga mengalami hal yang sama. Berdasarkan data yang diperoleh 
produksi padi di Riau mengalami peningkatan dari tahun 2014 sebesar 385,475 ton GKG, dan selanjutnya pada tahun 2015 sebesar 393,917 ton GKG atau meningkat sebesar 8,442 ton GKG dari tahun sebelumnya. Meningkatnya produksi padi di Riau juga disebabkan peningkatan luas panen padi pada tahun 2015 sebesar 107,546 ha atau sebesar 1,42\% dari tahun sebelumnya (Melba, 2016). Kabupaten Kampar yang merupakan salah satu sentra penghasil padi pada kenyataan masih mengalami devisit beras sebanyak 39.064,15 ton dari kebutuhan beras sebanyak $60.651,84$ ton atau sebesar $64,41 \%$ dari total kebutuhan (BPTP Riau, 2017). Kondisi lahan sawah di kabupaten Kampar juga semakin berkurang sehingga produktivitas padi semakin menurun. Agar produksi padi di kabupaten Kampar dapat meningkat perlu upaya-upaya yang dilakukan salah satunya dalam pelaksanaan usahatani padi. Mulai dari pemilihan input seperti jenis bibit, kebutuhan pupuk per luas tanam, penggunaan peralatan, pelaksanaan teknis budidaya yang tepat dan sebagainya. Untuk mendukung semua hal tersebut agar dapat terlaksana dengan baik perlu adanya perhitungan kebutuhan biaya atau modal mulai dari proses awal pengolahan lahan hingga panen dan pasca panen. Namun, petani padi khususnya tidak pernah melakukan perhitungan biaya maupun pendapatan yang diperoleh pada usahatani padinya.

Pada beberapa kecamatan di kabupaten Kampar, yang menghasilkan padi juga cukup banyak. Adapun data produksi padi di Kabupaten Kampar berdasarkan kecamatan, produksi tertinggi berada pada kecamatan Kampar dengan jumlah produksi 9.106,28 ton (5,02 ton/ha). Selanjutnya, diikuti Kecamatan Kampar Timur dengan jumlah produksi sebesar 5.301 ton $(4,75$ ton/ha), dan Kecamatan Bangkinang sebesar 4.852,10 ton (6,05 ton/ha). Namun, jika dilihat dari nilai produktivitasnya kecamatan Bangkinang merupakan daerah yang paling tinggi. Tingginya produktivitas di daerah tersebut bisa disebabkan adanya penggunaan benih unggul, teknis budidaya yang tepat, dan dekat dengan sumber air sehingga kebutuhan air selalu terpenuhi pada masa tanam.

Usahatani padi memerlukan teknis yang tepat untuk dapat meningkatkan produksi meskipun dengan lahan yang terbatas. Upaya untuk meningkatkan produksi padi khususnya di kecamatan Bangkinang, petani harus memperoleh banyak informasi baik dari penyuluh, dari petani lain ataupun dari media seperti media cetak, online dan sebagainya. Untuk memperoleh informasi tersebut petani memerlukan biaya, meskipun dalam jumlah yang kecil. Namun, petani pada umumnya seringkali tidak menyadari bahwa ada biayabiaya lainnya selain biaya produksi yang digunakan terkait dengan kegiatan usahataninya. Biaya-biaya yang dikeluarkan petani untuk mencari informasi usahatani, sumbangan untuk kelompok tani jika petani merupakan anggota kelompok tani, biaya pungutan tidak resmi disebut dengan biaya transaksi.

Petani padi di kecamatan Bangkinang yang saling memiliki keterlibatan dengan lembaga-lembaga seperti lembaga pemasaran, kelompok tani, pembiayaan atau usaha lainnya seperti penggilingan padi atau penyewaan alat dan mesin pertanian diduga dapat menimbulkan biaya transaksi. Adanya dugaan biaya transaksi ini terutama bagi petani padi dapat berpengaruh terhadap pendapatan atau keuntungan. Semakin banyaknya informasi yang didapat, semakin banyak juga biaya transaksi, tetapi informasi ini dapat memperbaiki kegiatan usahatani. Sehingga, secara umum dapat disimpulkan biaya transaksi dapat menurunkan keuntungan karena semakin meningkatnya biaya, namun pada kondisi lainnya biaya transaksi memberikan dampak yang baik pada usahatani padi karena petani dapat memperoleh informasi yang cukup. Berdasarkan permasalahan tersebut, dapat dirumuskan beberapa pertanyaan antara lain, Apa saja komponen biaya transaksi pada usahatani padi? Bagaimana pengaruh biaya transaksi terhadap efisiensi ekonomi usahatani padi? Berdasarkan beberapa uraian tersebut, maka tujuan yang ingin dicapai pada penelitian ini adalah (1) Mengidentifikasi dan menghitung komponen biaya transaksi pada usahatani padi; dan (2) Menganalisis pengaruh biaya transaksi terhadap efisiensi ekonomi usahatani padi.

\section{METODE PENELITIAN}

Lokasi penelitian dilakukan di Kecamatan Bangkinang yang dipilih secara purposive dengan pertimbangan lokasi penelitian merupakan daerah yang memiliki produktivitas padi paling tinggi dibandingkan kecamatan lainnya yaitu sebesar 6,05 ton/ha. 
Penelitian ini direncanakan selama 6 bulan, yang dimulai dari bulan Februari 2018 hingga Juli 2018,, dengan tahapan kegiatan meliputi penyusunan proposal penelitian, pengambilan data, pengolahan data, dan analisis data.

Populasi penelitian adalah kelompok petani padi sawah yang ada di daerah penelitian. Namun, jumlah populasi petani padi atau sampling frame belum diketahui sehingga jumlah sampel diambil sebanyak 50 sampel. Penentuan sampel dilakukan dengan teknik accidental sampling, yang mana penentuan jumlahnya diambil karena dianggap sudah representatif dan dapat mewakili jumlah populasi.

Data yang dikumpulkan dalam penelitian ini terdiri dari data primer dan sekunder. Data primer meliputi karakteristik petani padi (meliputi: umur, pendidikan, pengalaman berusaha, dan jumlah anggota rumah tangga). Selanjutnya, profil usahatani padi, meliputi luas lahan usaha dan status kepemilikan usaha, penggunaan input, produksi, harga, sarana produksi dan data lainnya yang dianggap penting. Data primer diperoleh melalui wawancara langsung dengan responden.

Selanjutnya, data sekunder dalam penelitian ini diperoleh dari instansi terkait, seperti: Badan Pusat Statistik (BPS) Kabupaten Kampar, Kantor Desa serta data dari instansi lainnya yang diperlukan dalam penelitian ini. Data sekunder meliputi keadaan lokasi penelitian, luas areal, iklim, demografi, topografi.

Biaya transaksi dihitung dengan tujuan untuk melihat besarnya biaya yang dikeluarkan oleh petani selain dari biaya produksi selama proses produksi, dan berkaitan dengan kepentingan usahatani padi. Biaya transaksi akan dianalisis dengan menggunakan rumus sebagai berikut:

$$
\operatorname{TrC}=\sum \mathrm{Zi}
$$

Untuk menghitung rasio masingmasing komponen biaya transaksi dapat digunakan rumus sebagai berikut:

$$
\mathrm{Z}=\mathrm{Zi} / \operatorname{TrC}: \sum \mathrm{Zi}=1
$$

Dimana:

$\operatorname{TrC}=$ Biaya transaksi $(\mathrm{Rp} /$ proses produksi)

$\mathrm{Zi}=$ rata-rata komponen biaya transaksi (Rp/th)

$\mathrm{Z} \quad$ = rasio biaya transaksi
Rasio biaya transaksi menunjukkan hubungan antara penerimaan dari usahatani dengan jumlah biaya transaksi. Rasio biaya transaksi bernilai maksimal sama dengan 1 (rasio biaya transaksi <1). Semakin besar rasio biaya transaksi terhadap total biaya, semakin tidak efisien suatu kegiatan usahatani.

Analisis tingkat efisiensi ekonomi usahatani padi diukur melalui nisbah biaya transaksi terhadap penerimaan yang menggunakan persamaan sebagai berikut:

$$
\mathrm{Zj}=\operatorname{TrC} / \mathrm{TR}
$$

Keterangan :

$\mathrm{Zj}$ = nisbah biaya transaksi - penerimaan

$\operatorname{TrC}=$ biaya transaksi (Rp/proses produksi)

$\mathrm{TR}=$ total penerimaan $(\mathrm{Rp} /$ proses produksi)

Pengaruh komponen biaya transaksi terhadap biaya transaksi usahatani padi dilakukan dengan analisis regresi berganda dengan persamaan sebagai berikut:

$$
\begin{aligned}
\operatorname{TrC}= & a 0+a 1 X 1+a 2 X 2+a 3 X 3+a 4 X 4+ \\
& a 5 X 5+a 6 X 6+a 7 X 7+\mu
\end{aligned}
$$

$(\mathrm{a} 0, \mathrm{a} 1, \mathrm{a} 4, \mathrm{a} 6, \mathrm{a} 7>0$ dan a2, a3, a5 < 0)

$$
\begin{aligned}
& \text { Keterangan: } \\
& \operatorname{TrC}=\text { Biaya transaksi } \\
& \mathrm{X} 1=\text { Umur } \\
& \mathrm{X} 2 \text { = Jumlah anggota keluarga } \\
& \mathrm{X} 3 \text { = Pengalaman berusaha } \\
& \mathrm{X} 4=\text { Pendidikan } \\
& \mathrm{X} 5 \text { = Output } \\
& \mathrm{X} 6 \text { = Pencarian informasi } \\
& \mathrm{X} 7 \text { = Iuran }
\end{aligned}
$$

\section{HASIL DAN PEMBAHASAN}

Penentuan masing-masing komponen biaya transaksi berdasarkan hasil penelitian, dibagi menjadi dua bagian yaitu biaya transaksi pengadaan input usahatani padi dan biaya transaksi pengadaan output usahatani padi. Secara umum, biaya transaksi pengadaan input usahatani padi terdiri dari beberapa komponen yakni biaya informasi, biaya negosiasi, biaya koordinasi dan biaya pelaksanaan. Komponen biaya transaksi pengadaan output lebih sedikit dibandingkan pada pengadaan input, yang mana biaya transaksi nya terdiri dari biaya risiko dan biaya transportasi. Setiap komponen biaya transaksi baik pada pengadaan input maupun pengadaan output merupakan biaya yang dikeluarkan oleh 
petani mulai dari persiapan sebelum tanam hingga pasca panen.

Total keseluruhan biaya transaksi usahatani padi adalah sebesar Rp 98.076. Dari total tersebut faktor yang paling mendominasi adalah biaya koordinasi dengan jumlah ratarata sebesar Rp 77.700 (82,49\%). Petani memiliki kewajiban membayar iuran untuk kebutuhan usahatani padi terutama pada kegiatan pengolahan lahan yang dilakukan dengan sistem batobo. Hal ini selain membantu memudahkan petani dalam pengolahan lahan tetapi juga bertujuan untuk melestarikan budaya gotong royong di daerah penelitian untuk meningkatkan rasa kebersamaan dan mempererat hubungan silahturahmi antar petani padi. Seperti yang diungkapkan oleh Anggraini (2007), biaya transaksi dapat muncul pada suatu usaha karena dipengaruhi kondisi di suatu daerah baik sosial, ekonomi dan budaya maupun kebijakan pemerintah setempat. Selain biaya koordinasi, komponen biaya transaksi usahatani padi lainnya dapat dilihat pada Tabel 1 sebagai berikut.

Berdasarkan tabel 1 dapat dilihat jumlah masing-masing komponen biaya transaksi usahatani padi dengan biaya paling tinggi terdapat pada biaya koordinasi dan biaya paling rendah terdapat pada biaya negosiasi. Besar kecilnya jumlah biaya transaksi akan mempengaruhi jumlah biaya yang dikeluarkan petani pada usahatani padi. Jika semakin besar biaya transaksi, maka semakin besar biaya usahatani dan pendapatan usahatani padi akan semakin berkurang. Namun, biaya yang dikeluarkan petani yang termasuk ke dalam biaya transaksi terkadang tidak diketahui oleh petani.

Tabel 1. Jumlah biaya transaksi usahatani padi di kecamatan Bangkinang kabupaten Kampar

\begin{tabular}{|c|c|c|c|c|c|}
\hline \multirow[b]{2}{*}{ No } & \multirow{2}{*}{$\begin{array}{c}\text { Komponen Biaya } \\
\text { Transaksi }\end{array}$} & \multicolumn{2}{|c|}{ Jumlah (Rp) } & \multirow[b]{2}{*}{ Persentase (\%) } & \multirow[b]{2}{*}{ Rasio } \\
\hline & & $\begin{array}{l}\text { Pengadaan } \\
\text { Input }\end{array}$ & $\begin{array}{c}\text { Pengadaan } \\
\text { Output }\end{array}$ & & \\
\hline 1 & Biaya informasi & 4.540 & - & 4,62 & 0,05 \\
\hline 2 & Biaya negosiasi & 1.970 & - & 2,01 & 0,02 \\
\hline 3 & Biaya koordinasi & 77.700 & - & 79,22 & 0,79 \\
\hline 4 & Biaya pelaksanaan & 3.146 & - & 3,21 & 0,03 \\
\hline 5 & Biaya risiko & - & 7.820 & 7,97 & 0,08 \\
\hline 6 & Biaya transportasi & - & 2.900 & 2,95 & 0,03 \\
\hline \multicolumn{2}{|c|}{ Jumlah } & 87.356 & 10.720 & 100,00 & 1,00 \\
\hline
\end{tabular}

Total biaya transaksi

Setelah mengetahui jumlah dan komponen biaya transaksi pada usahatani padi di kecamatan Bangkinang, selanjutnya berdasarkan jumlah biaya transaksi tersebut dapat dihitung rasio biaya transaksi terhadap penerimaan usahatani padi. Rasio tertinggi juga terdapat pada biaya koordinasi dengan rasio sebesar 0,79 . Nilai rasio ini menunjukkan bahwa setiap $\mathrm{Rp} 1$ biaya koordinasi yang dikeluarkan, maka biaya usahatani akan bertambah sebesar $\mathrm{Rp}$ 0,79. Jika biaya usahatani meningkat, maka penerimaan usahatani padi akan berkurang Rp 0,79. Biaya risiko juga memiliki rasio yang cukup tinggi yaitu sebesar 0,08 yang menunjukkan bahwa, setiap Rp 1 biaya risiko yang dikeluarkan petani, maka akan meningkatkan biaya usahatani sebesar Rp 0,08 dan penerimaan akan menurun sebesar Rp 0,08. Rasio biaya transaksi terendah terdapat pada biaya negosiasi yaitu sebesar 0,02 . Rasio ini menunjukkan jika petani mengeluarkan biaya negosiasi sebesar $\mathrm{Rp} 1$, maka total biaya usahatani akan bertambah sebesar Rp 0,02 dan penerimaan usahatani akan menurun sebesar $\mathrm{Rp} 0,02$. Untuk biaya informasi rasio nya bernilai 0,05 , dan biaya pelaksanaan serta biaya transportasi memiliki rasio yang juga cukup kecil, dengan masing-masing rasio bernilai 0,03 . Meskipun nilai rasio biaya tersebut kecil, tetapi juga akan berpengaruh terhadap penerimaan usahatani padi di daerah penelitian.

Rasio biaya transaksi berhubungan positif dengan total biaya usahatani yang mana jika biaya transaksi semakin besar, maka biaya usahatani juga semakin meningkat. Tetapi, rasio biaya transaksi berhubungan negatif terhadap penerimaan. Dimana, jika biaya transaksi bertambah maka penerimaan akan berkurang. Menurut Anggraini (2007), biaya transaksi tidak dapat dihindari tetapi biaya transaksi dapat diminimumkan agar efisiensi 
suatu usaha dapat meningkat. Karena semakin banyak biaya yang dikeluarkan maka semakin tidak efisien suatu usaha. Begitu juga dengan biaya transaksi, semakin tinggi biaya transaksi yang dikeluarkan maka semakin tidak efisien usaha tersebut.

Suatu usaha dapat dikatakan efisien apabila mampu menghasilkan penerimaan yang lebih besar dibandingkan biaya yang dikeluarkan. Rata-rata penerimaan usahatani padi di daerah penelitian adalah sebesar $\mathrm{Rp}$ 10.219.500/musim tanam. Sedangkan, total biaya produksi adalah sebesar $\mathrm{Rp}$ 7.037.582/musim tanam. Untuk menilai tingkat pengaruh biaya transaksi terhadap efisiensi ekonomi usahatani padi, dapat dihitung nisbah biaya transaksi terhadap penerimaannya. Hasil perhitungan diperoleh nisbah dengan nilai sebesar 0,009. Nilai ini memiliki makna bahwa setiap penerimaan Rp 100 yang diperoleh dari usahatani padi, terjadi pengeluaran modal atau uang oleh petani sebesar Rp 9 dalam bentuk biaya transaksi. Kondisi ini berdampak terhadap keuntungan yang akan diterima petani padi. Dimana, rata-rata keuntungan semula yang diperoleh petani padi adalah sebesar $\mathrm{Rp}$ 3.181.918/musim tanam, dengan adanya biaya transaksi yang dikeluarkan sebesar Rp 98.076, keuntungan yang benar-benar dapat dinikmati petani menjadi sebesar Rp 3.083.842/musim tanam.

Meskipun biaya transaksi dapat mengurangi keuntungan usahatani padi, bila dikaji lebih lanjut pengeluaran biaya transaksi ini juga dapat memberikan dampak yang positif bagi petani maupun usahatani padi. Pada biaya informasi, petani akan mengeluarkan sejumlah biaya untuk mencari informasi terkait permasalahan pada usahataninya. Jika petani tidak mencari dan mendapatkan informasi, petani tentu tidak bisa menyelesaikan masalahnya seperti memberantas hama penyakit tanaman padi, informasi mengenai adanya bantuan kepada petani dan informasi lainnya. Dampaknya bagi petani yaitu akan menambah pengetahuan dan pengalamannya dalam melakukan dan memperbaiki pengelolaan usahatani. Begitu juga dengan biaya negosiasi, petani tidak perlu berulang kali mencari tenaga kerja dari luar keluarga untuk membantu pengerjaan usahatani. Pada biaya koordinasi juga telah dijelaskan sebelumnya bahwa biaya ini memiliki dampak terhadap pengelolaan usahatani terutama pada pengerjaan pengolahan lahan yang dilakukan secara batobo serta menjaga kelestarian budaya gotong royong di daerah penelitian dan menjaga silahturahmi antar petani. Sehingga, dapat disimpulkan bahwa meskipun terdapat tambahan pengeluaran berupa biaya transaksi pada usahatani padi, namun ada manfaat atau output lain yang bisa diterima petani padi walaupun tidak dalam bentuk materi.

Tabel 2. Hasil output SPSS faktor-faktor yang berpengaruh terhadap biaya transaksi usahatani padi di kecamatan Bangkinang kabupaten Kampar

\begin{tabular}{clrrrr}
\hline No & \multicolumn{1}{c}{ Parameter } & \multicolumn{1}{c}{ Koefisien } & \multicolumn{1}{c}{ t-sig } & \multicolumn{1}{c}{ P-value } & \multicolumn{1}{c}{ VIF } \\
\hline 1 & Konstanta & 36968,023 & 1,392 & 0,171 & - \\
2 & Umur (X1) & $-798,574$ & $-1,245$ & 0,220 & 2,479 \\
3 & Jumlah anggota keluarga (X2) & 836,931 & 0,326 & 0,746 & 1,960 \\
4 & Pengalaman berusaha (X3) & 1157,944 & 1,501 & $0,141^{*}$ & 1,566 \\
5 & Pendidikan (X4) & 1016,867 & 0,607 & 0,547 & 1,348 \\
6 & Output (X5) & $-5,105$ & $-0,808$ & 0,424 & 1,400 \\
7 & Pencarian informasi (X6) & 2157,534 & 0,893 & 0,377 & 1,212 \\
8 & Iuran (X7) & 31445,574 & 22,578 & $0,000^{* * *}$ & 1,247 \\
\hline $\mathrm{R}^{2}$ & & & & $93,70 \%$ \\
Adj R & & & & $92,60 \%$ \\
SEE & & & & 20123,365 \\
F & & & & 88,491 \\
Sig & & & & 0,000 \\
\hline Ke
\end{tabular}

Keterangan: $* * *=$ berpengaruh nyata pada tingkat $\alpha 5 \%, *=$ berpengaruh nyata pada tingkat $\alpha 15 \%$

Total biaya transaksi usahatani padi di daerah penelitian dipengaruhi oleh jumlah dari masing-masing komponen biaya transaksi. Namun, dalam penelitian ini untuk melihat faktor apa yang paling berpengaruh terhadap biaya transaksi tersebut perlu dilakukan uji dengan analisis regresi berganda. Dimana total biaya transaksi ( $\mathrm{TrC})$ menjadi variabel dependent pada analisis tersebut. Sedangkan, yang menjadi variabel independentnya antara 
lain, umur (X1), jumlah anggota keluarga (X2), Pengalaman berusahatani (X3), Pendidikan (X4), Jumlah produksi/output (X5), pencarian informasi (X6), dan iuran (X7). Hasil pengujian faktor-faktor yang berpengaruh terhadap biaya transaksi usahatani padi di daerah penelitian selengkapnya dapat dilihat pada Tabel 2.

Setelah dilakukan pengujian model regresi dan diperoleh hasil yang menunjukkan bahwa analisis regresi dapat dilanjutkan, maka analisis regresi baru bisa dilakukan. Dari hasil analisis regresi yang telah dilakukan, menunjukkan bahwa terdapat 2 variabel bebas yang berpengaruh signifikan terhadap biaya transaksi. Terdapat 1 variabel yang berpengaruh signifikan terhadap biaya transaksi pada taraf nyata $15 \%(\alpha=15 \%)$, yaitu variabel pengalaman berusaha (X3). Sedangkan 1 variabel lainnya adalah iuran (X7) berpengaruh signifikan terhadap biaya transaksi pada taraf nyata $5 \%(\alpha=5 \%)$. Pada hasil analisis regresi yang dilakukan, dapat ditulis persamaan regresi sebagai berikut.

$$
\begin{aligned}
\operatorname{TrC}= & 36968,023-798,574 \mathrm{X} 1+836,931 \mathrm{X} 2+ \\
& 1157,944 \mathrm{X} 3+1016,867 \mathrm{X} 4-5,105 \mathrm{X} 5+ \\
& 2157,534 \mathrm{X} 6+31445,574 \mathrm{X} 7+\mathrm{e}
\end{aligned}
$$

Variabel-variabel yang mempengaruhi biaya transaksi usahatani padi ada yang menunjukkan hubungan positif dan ada juga beberapa variabel yang menunjukkan hubungan negatif. Variabel yang menunjukkan hubungan positif antara lain jumlah anggota keluarga (X2), pengalaman usaha (X3), Pendidikan (X4), pencarian informasi (X6) dan iuran (X7). Variabel yang berhubungan positif artinya setiap peningkatan nilai variabel akan meningkatkan jumlah biaya transaksi. Pada variabel jumlah anggota keluarga (X2) tidak berpengaruh nyata terhadap biaya transaksi. Namun, jika dilihat dari nilai koefisiennya variabel ini memiliki hubungan yang positif, yang berarti bahwa jika terjadi kenaikan jumlah anggota keluarga sebanyak 1 jiwa, maka biaya transaksi juga akan meningkat sebesar Rp 836,931. Seharusnya, jumlah anggota keluarga memeiliki hubungan yang negatif terhadap biaya transaksi. Hal ini disebabkan, semakin banyaknya jumlah anggota keluarga maka semakin banyak anggota keluarga yang bias dimanfaatkan sebagai tenaga kerja. Hanya saja, di daerah penelitian sangat sedikit anggota keluarga yang dijadikan sebagai tenaga kerja. Sehingga, petani padi tetap harus mencari tenaga kerja luar keluarga yang menyebabkan biaya transaksi juga meningkat.

Begitu juga dengan pengalaman usaha (X3) yang memiliki pengaruh nyata terhadap biaya transaksi dengan koefisien sebesar 1157,944 . Nilai ini menunjukkan bahwa jika terjadi kenaikan biaya koordinasi sebesar Rp 1, maka biaya transaksi juga akan meningkat sebesar $\mathrm{Rp} 1.157,944$. Pada variabel Pendidikan (X4) juga memiliki koefisien yang positif dengan nilai sebesar 1016,86. Koefisien ini menunjukkan dengan semakin tingginya tingkat pendidikan, semakin tinggi keingintahuan petani dan penggunaan teknologi baru sehingga biaya transaksi akan meningkat sebesar Rp 1.016,86. Variabel selanjutnya adalah pencarian informasi dengan koefisien sebesar 2157,534, yang berarti jika semakin meningkat frekuensi pencarian informasi oleh petani sebesar 1 satuan maka akan meningkatkan biaya transaksi sebesar Rp 2.157,534. Variabel iuran (X7) juga memiliki hubungan yang positif terhadap biaya transaksi. Koefisien variabel X7 adalah sebesar 31445,574 , yang berarti jika semakin meningkat frekuensi pembayaran iuran oleh petani sebesar 1 satuan maka akan meningkatkan biaya transaksi sebesar $\mathrm{Rp}$ 31.445,574. Variabel X7 juga berpengaruh signifikan terhadap biaya transaksi dengan tingkat signifikan berada pada $\alpha 5 \%$. Dengan semakin banyaknya variabel yang berpengaruh positif semakin meningkat pula biaya transaksi. Hal ini juga menyebabkan, akan semakin banyak biaya yang secara tidak langsung dikeluarkan oleh petani yang juga berdampak pada semakin berkurangnya penerimaan dan keuntungan usahatani padi.

Variabel berikutnya yang berpengaruh negatif terhadap biaya transaksi adalah umur (X1), dan total output (X5). Variabel umur memiliki koefisien dengan nilai sebesar 798,574. Koefisien tersebut menunjukkan bahwa apabila umur petani meningkat 1 satuan, maka total biaya transaksi akan menurun sebesar -798,574. Secara hipotesis, seharusnya umur memiliki hubungan yang positif terhadap biaya transaksi. Hal ini bisa saja terjadi, karena dengan meningkatnya umur semakin produktif petani dalam pencarian informasi yang menghasilkan keluaran biaya lebih kecil. Berkaitan dengan informasi, jika semakin banyak informasi yang diterima petani secara tidak langsung akan memperbaiki 
pengelolaan usahatani padi sehingga biaya transaksi dari komponen lainnya bisa lebih rendah dan biaya transaksi secara keseluruhan juga akan lebih rendah.

Variabel terakhir yang memiliki hubungan negatif terhadap biaya transaksi adalah total output atau total produksi (X5). Variabel ini memiliki koefisien sebesar $-5,105$ dan tidak berpengaruh nyata terhadap biaya transaksi. Koefisien variabel total produksi memiliki arti bahwa jika total produksi meningkat sebesar $1 \mathrm{~kg}$ maka biaya transaksi menurun sebesar $\mathrm{Rp} 5,105$. Hasil ini juga sejalan dengan penelitian yang dilakukan oleh Mohamad et.al (2014), dimana hasil penelitiannya menunjukkan bahwa total produksi berhubungan negatif terhadap biaya transaksi usaha jagung pipilan kering. Koefisien pada variabel tersebut sebesar 0,588 . nilai ini menunjukkan bahwa semakin tinggi produksi yang dihasilkan oleh petani maka semakin menurun pembebanan biaya transaksi per unit yang ditanggung oleh petani tersebut secara agregatnya. Sehingga dapat disimpulkan, semakin besar nilai koefisiennya maka akan semakin baik.

\section{KESIMPULAN}

Komponen biaya transaksi usahatani padi di daerah penelitian terdiri dari biaya informasi, biaya negosiasi, biaya koordinasi, biaya pelaksanaan, biaya risiko, dan biaya transportasi. Jumlah biaya transaksi usahatani padi adalah sebesar Rp 98.076. Persentase biaya transaksi terbesar adalah biaya koordinasi $(79,22 \%)$, dan persentase biaya transaksi terkecil adalah biaya negosiasi $(2,01$ $\%)$. Rasio masing-masing komponen biaya transaksi, untuk biaya informasi sebesar 0,05, biaya negosiasi sebesar 0,02 , biaya koordinasi sebesar 0,79. Rasio biaya pelaksanaan sebesar 0,03 , biaya risiko 0,08 dan biaya transportasi sebesar 0,03 .

Biaya transaksi dapat mempengaruhi efisiensi usahatani padi, dimana adanya tambahan biaya selain biaya usahatani. Semakin banyak biaya yang dikeluarkan semakin sedikit keuntungan yang diterima petani. Pengaruh biaya transaksi terhadap efisiensi usahatani padi dapat dilihat dari nisbah biaya transaksi terhadap penerimaan usahatani padi yaitu sebesar 0,009 . Sedangkan, keuntungan yang diperoleh petani setelah dikurangi biaya transaksi menjadi $\mathrm{Rp}$ 3.083.842/musim tanam. Adapun faktor-faktor yang berpengaruh nyata terhadap biaya transaksi adalah pengalaman berusaha (X3) dan iuran (X7).

\section{DAFTAR PUSTAKA}

Anggraini, E. 2007. Biaya Transaksi Usaha Penangkapan Ikan di Kota Pekalongan. Jurnal Ilmu Pertanian Indonesia. Vol 12 No 1.

BPTP Riau. 2017. Kajian Produktivitas Padi Sawah di Kabupaten Kampar. BPTP Balitbangtan Riau. Pekanbaru. Riau.

Melba. 2016. Luas Area Panen Bertambah, Produksi Padi di Riau Meningkat. Bertuahpos.com

Mohamad MAA, Dwidjono HD, Soeratno, Salmet H. 2014. Analisis Biaya Transaksi Jagung Hibrida di Provinsi Gorontalo. Vol 11 No 1. Jurnal SEPA.

Picot, A. 1981. Transactions Cost and Theorie der Organisation. Hannover: Lehrgebiet für BWL, Universität Hannove.

Wang, N. 2003. Measuring Transaction Cost: An Incomplete Survey. Ronal Coase Institute. Working Paper.

Williamson OE. 1989. Transaction Cost Economics: An Introduction. Handbook of Industrial Organization, Volume 1. Elsevier Science Publishers B.V. 1989. University of California, Berkeley. 
